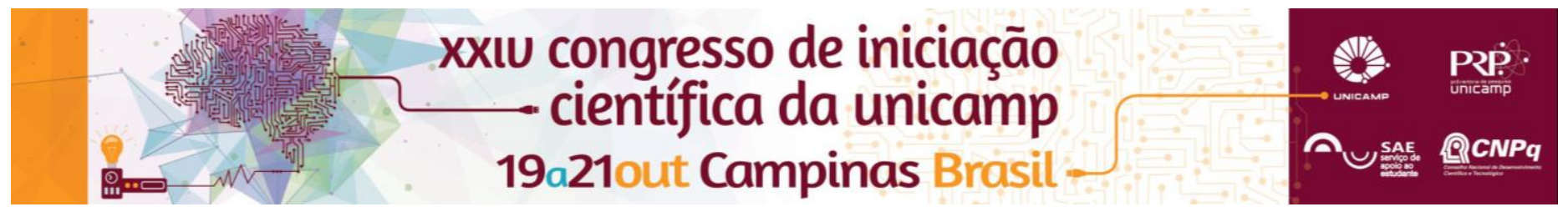

\title{
Aplicação de microreatores na síntese de biodiesel através da transesterificação do óleo de farelo de arroz
}

\author{
Alan C. Rodrigues*, Harrson S. Santana, Osvaldir P. Taranto .
}

\section{Resumo}

Alguns pesquisadores estão investigando a utilização do óleo de farelo de arroz na produção de biodiesel sendo que a produção e pesquisa da reação de transesterificação do óleo de farelo de arroz geralmente ocorrem em reatores batelada. Em virtude disso, este estudo tem como objetivo estudar a síntese de biodiesel em microreatores a partir do óleo de farelo de arroz em duas etapas: esterificação e transesterificação, devido ao alto índice de acidez que o óleo apresenta. Foi estudada a influência das variáveis: temperatura, razão etanol/óleo e diferentes modelos de microreatores. A máxima porcentagem de diminuição do índice de acidez encontrada para a reação de esterificação foi de $74,40 \%$ para MSO (Microreator com obstáculos esféricos) com vazão 9:1 etanol/óleo e catalisador $\mathrm{H}_{2} \mathrm{SO}_{4} 1 \% \mathrm{~m} / \mathrm{m}$. Os resultados comprovaram a eficiência dos microreatores na esterificação do óleo de farelo de arroz.

\section{Palavras-chave}

Microreator, esterificação, farelo de arroz.

\section{Introdução}

A necessidade de afastar-se de um sistema baseado na petroquímica, um aumento da conscientização e esgotamento dos recursos ambientais, leva ao aumento do uso de biocombustíveis. Entre esses biocombustíveis, o biodiesel destaca-se por apresentar vantagens, que 0 torna ambiental, social $e$ economicamente interessante. Alguns pesquisadores estão investigando a utilização do óleo de farelo de arroz na produção de biodiesel, sendo que essa produção geralmente ocorre em reatores batelada e necessitam de uma ou várias horas para se alcançar altos índices de rendimento. Nesse sentido, este estudo tem como objetivo estudar a síntese de biodiesel em microreatores a partir do óleo de farelo de arroz em duas etapas: esterificação, para converter os ácidos graxos livres em ésteres, utilizando um catalisador ácido $\left(\mathrm{H}_{2} \mathrm{SO}_{4} 1 \% \mathrm{~m} / \mathrm{m}\right)$ e assim reduzir o índice de acidez do óleo a um valor abaixo de $1 \mathrm{mg} \mathrm{KOH} . \mathrm{g}^{-1} \mathrm{e}$, por fim, realizar a transesterificação com um catalisador alcalino a fim de produzir biodiesel.

\section{Resultados e Discussão}

Os experimentos foram realizados em três microreatores: MST (sem obstáculos), MSE (com elementos estáticos) e MSO (com obstáculos circulares). Os resultados obtidos são mostrados na Figura 1. As maiores porcentagens de diminuição do índice de acidez através da esterificação foram obtidas para o microreator MSO com $74,4 \%$ à $50^{\circ} \mathrm{C}$ razão $9: 1$ e $66,6 \%$ à $50^{\circ} \mathrm{C}$ razão 6:1.

Esse resultado provavelmente está associado a elevada área superficial em relação ao volume, o que permite obter altas taxas de transferência de massa e calor, e um curto comprimento de difusão dos reagentes, quando comparados aos reatores convencionais.
Figura 1. Efeito da Temperatura e tipo de microreator no Índice de Acidez (\%) para razão molar 9:1 e catalisador $1 \% \mathrm{~m} / \mathrm{m}$

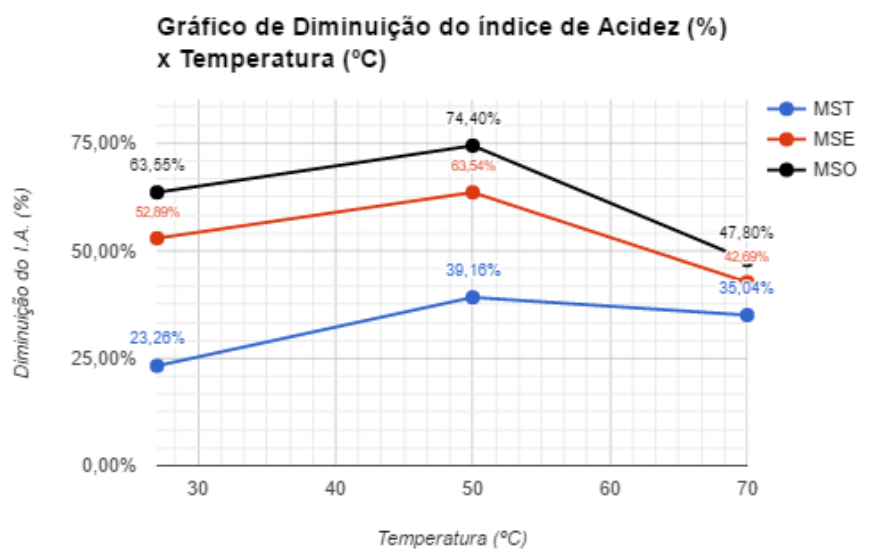

Figura 2. Efeito da razão molar (etanol:óleo) na diminuição do Índice de Acidez (\%) no microreator MSO.

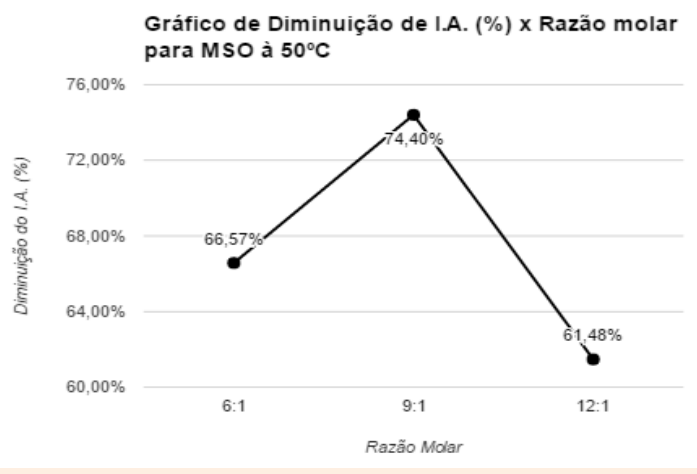

\section{Conclusões}

A máxima porcentagem de diminuição de Índice de Acidez foi obtida para o microreator MSO à $50 \stackrel{\circ}{ } \mathrm{C}$ razão molar 9:1 com 10 segundos de tempo de residência obtendo $74,40 \%$. Pode-se concluir que os microreatores são uma opção viável para a etapa de esterificação do óleo de farelo de arroz para a produção de biodiesel.

\section{Agradecimentos}

